\title{
The influence of silver thiosulfate and thidiazuron on shoot regeneration from cotyledon explants of Brassica napus
}

\author{
Kyung Hee Roh $\cdot$ Bo-Kyung Kwak $\cdot$ Jong-Bum Kim $\cdot$ Kyeong-Ryeol Lee $\cdot$ Hyun Uk Kim $\cdot$ Sun Hee Kim
}

Received: 3 September 2012 / Accepted: 10 September 2012

(C) Korean Society for Plant Biotechnology

\begin{abstract}
The influences of ethylene inhibitors $\left(\mathrm{AgNO}_{3}\right.$ and silver thiosulfate) and cytokinins (BAP and TDZ) on shoot regeneration from cotyledon and hypocotyl explants of B. napus cv. Youngsan were investigated. The presence of $50 \mu \mathrm{M}$ Silver thiosulfate (STS) in shoot regeneration medium formed shoots at $60-68 \%$ after 3-4 weeks of culture, which was enhanced by 2 -fold compared to that of Silver nitrate $\left(\mathrm{AgNO}_{3}\right)$. Moreover, cotyledon explants were more regenerative than hypocotyls; shoots from cotyledon explants began to occur 4-5 days earlier than that of hypocotyl explants. TDZ at a concentration of $8-10 \mu \mathrm{M}$ was effective for shoot regeneration, compared with BAP. Consequently, the optimal shoot regeneration response was observed in medium supplemented with $50 \mu \mathrm{M}$ STS $+8 \mu \mathrm{M}$ TDZ. In transmission electron microscopy (TEM) analysis, higher density of silver nanoparticles was shown to be accumulated widely inside the cell wall and plasmodesmata of regenerating leaf cultured in medium supplemented with $\mathrm{AgNO}_{3}$. By contrast, in the cell cultured in medium with STS, fine-grained deposits were partly observed in the surroundings of the cell wall.
\end{abstract}

Keywords cytokinin, ethylene inhibitor, oilseed rape, rapeseed, silver nanoparticles

\section{Introduction}

Rapeseed (Brassica napus) is now the second largest oilseed crop after soybean and the third largest vegetable oil after soybean oil and palm oil. Since transgenic plants in $B$. napus were reported by De Block et al. (1989) and Moloney

K. H. Roh $(\bowtie) \cdot$ B.-K. Kwak ·J.-B. Kim • K.-R. Lee •

H. U. Kim - S. H. Kim

Department of Agricultural Biotechnology, National Academy of Agricultural Science, RDA, Suwon 441-707, Korea

e-mail: rohkh@korea.kr et al. (1989), regeneration and transformation protocols of B. napus have been developed continuously. The ability to regenerate plants affects the transformation efficiency. Therefore, regeneration frequency is important to achievement of plant breeding using biotechnology.

Factors affecting the regeneration of Brassica species including B. napus have been investigated. On most Brassica species, regeneration is highly genotype-dependent (Poulsen 1996). Of the 100 genotypes of B. napus tested, a huge variation was observed in regeneration frequency, ranging from $0 \%$ to $91 \%$ (Ono et al. 1994). In addition, the ethylene inhibitor is an important factor to regenerate of Brassica species. Ethylene, a gaseous plant hormone, is produced during in vitro plant tissue culture. Ethylene accumulated in culture dishes has been shown to cause poor regeneration or abnormal growth and development of plant (Chi and Pua 1989; Chi et al. 1991; Eapen and George 1997). Early observations on the effects of ethylene in plant growth describe that ethylene inhibits cell division, DNA synthesis and growth in the meristems of roots, shoots, and axillary buds (Gane 1934; Apelbaum et al. 1972). Since it was published that ethylene inhibitors enhanced shoot regeneration of Brassica campestris (Chi and Pua 1989), similar results (Pental et al. 1990; Sethi et al. 1990; Williams et al. 1990; Palmer 1992; Pua and Chi 1993) of the plant regeneration in vitro in Brassica species have been reported and now it has been known as ethylene inhibitors are necessary for Brassica regeneration. In general, Silver nitrate is routinely used as an ethylene inhibitor. Other ethylene inhibitors such as Silver thiosulfate (Eapen and George 1997) and Aminoethoxyvinylglycine (Chi et al. 1990) have also been reported to have a positive effect on regeneration in Brassica species.

However, silver ions released from silver compound are accumulated itself into plant cells or react with compounds such as a chelating agent (EDTA) dissolved in culture medium to form silver nanoparticles, which are deposited 
eventually inside plant cells through pores of cell wall (Harris and Bali 2008; Mazumda and Ahmed 2011). Several studies on phytotoxicity and genotoxicity of silver nanoparticles in organisms including plants have been reported (Ratte 1999; Asharani et al. 2009; Yin et al. 2011). According to Adams and Kramer (1998), the solubility of a silver compound and the presence of complexing agents (e.g., thiosulfate or chloride) can determine the toxicity of silver. Recently, Steinitz and Bilavendran (2011) showed that silver thiosulfate was superior to $\mathrm{AgNO}_{3}$ in enhancing root culture, due to alleviate of silver toxicity by thiosulfate.

The aim of this study is to investigate the effects of ethylene inhibitors $\left(\mathrm{AgNO}_{3}\right.$ and silver thiosulfate) and cytokinins (BAP and TDZ) on shoot regeneration from cotyledon and hypocotyl explants of B. napus cv. Youngsan.

\section{Materials and methods}

Plant materials

Seeds of B. napus cv. Youngsan (from Bio-energy Crop Research Center, Muan, Republic of Korea) were surfacesterilized by dipping into $70 \%(\mathrm{v} / \mathrm{v})$ ethanol for $4 \mathrm{~min}$, followed by $30 \mathrm{~min}$ at $1.3 \%(\mathrm{v} / \mathrm{v})$ Sodium hypochlorite solution containing $0.01 \%$ Tween 20 , then rinsed three times with sterilized water and germinated at a density of 30 seeds per $100 \times 40 \mathrm{~mm}$ Petri dish containing hormonefree MS medium (Murashige and Skoog 1962) supplemented with $3 \%(\mathrm{w} / \mathrm{v})$ Sucrose and $0.3 \%(\mathrm{w} / \mathrm{v})$ Phytagel. Cultures were maintained under a $16-\mathrm{h}$ light/ $/ 8$ h dark cycle at $25 \pm$ $1^{\circ} \mathrm{C}$. Cotyledons, including the $1-2 \mathrm{~mm}$ petiole, and 7-10 $\mathrm{mm}$ long hypocotyls were excised from 5-day-old seedlings and cultured on shoot regeneration medium (SRM).

\section{Shoot regeneration}

In all experiments reported here, all components except $\mathrm{GA}_{3}$ (gibberellic acid), TDZ and ethylene inhibitors (Silver nitrate and Silver thiosulfate) were added to the medium and the $\mathrm{pH}$ adjusted to 5.8 before autoclaving at $121^{\circ} \mathrm{C}$ for $15 \mathrm{~min}$. SRM was composed of MS-MES media containing $500 \mathrm{mg} \cdot \mathrm{L}^{-1} \mathrm{PVP}$ (Polyvinylpyrrolidone), $40 \mathrm{mg} \cdot \mathrm{L}^{-1}$ Adenine hemisulphate, $0.1 \mu \mathrm{M} \mathrm{GA}_{3}, 1 \mu \mathrm{M}$ NAA (Naphthalene acid), $10 \mu \mathrm{M}$ BAP, $20 \mathrm{~g}$ Sucrose and $0.4 \mathrm{~g} \cdot \mathrm{L}^{-1}$ Phytagel. Media and all components except phytagel used in this experiment were purchased from Duchefa (Haarlem, The Netherlands) and Phytagel from Sigma-Aldrich (USA). Silver thiosulfate was prepared as follows: $0.1 \mathrm{M}$ Sodium thiosulfate stock solution was prepared by dissolving 1.58 $\mathrm{g}$ of Sodium thiosulfate into $100 \mathrm{ml}$ of water and $0.1 \mathrm{M}$ Silver nitrate stock solution was prepared by dissolving $1.7 \mathrm{~g}$ of Silver nitrate in $100 \mathrm{ml}$ of water and was filter-sterilized, $0.02 \mathrm{M}$ Silver thiosulfate solution was prepared by slowly pouring $20 \mathrm{ml}$ of $0.1 \mathrm{M}$ Silver nitrate stock solution in $80 \mathrm{ml}$ of $0.1 \mathrm{M}$ Sodium thiosulfate stock solution. Silver nitrate $\left(\mathrm{AgNO}_{3}\right)$ and Silver thiosulfate (STS) at the concentration of $30,40,50,60,70 \mu \mathrm{M}$ were added separately to the autoclaved SRM medium. BAP and TDZ at the concentration of $4,6,8,10,20 \mu \mathrm{M}$ were added separately to the autoclaved SRM medium containing 50 $\mu \mathrm{M} \mathrm{AgNO}$. Optimization for shoot regeneration was subsequently conducted by culturing cotyledon explants in SRM supplemented with a combination of ethylene inhibitors $\left(60 \mu \mathrm{M} \mathrm{AgNO}_{3}\right.$ and $50 \mu \mathrm{M}$ STS $)$ and cytokinins $(10 \mu \mathrm{M}$ BAP and $8 \mu \mathrm{M}$ TDZ). After 4-5 weeks of culture, explants were evaluated in terms of percent shoot regeneration, mean number of shoots, mean shoot length and mean fresh weight per explant. Each treatment consisted of 5-15 replicates (dishes) each with 10 explants. All investigations were repeated and the results were pooled. For statistical analysis, each plate was treated as one replication in the Duncan's multiple range tests (DMRT).

Specimen preparation for Transmission electron microscopy (TEM)

After 28 days of culture, regenerative leaf from cotyledon explants in medium containing $50 \mu \mathrm{M} \mathrm{AgNO}_{3}$ or $50 \mu \mathrm{M}$ STS was isolated and cut into small blocks of about 1-1.2 mm and fixed overnight at $4^{\circ} \mathrm{C}$ in Karnovsky (1965) fixative at $\mathrm{pH}$ 7.2. Following fixation, tissues were washed with $0.05 \mathrm{M}$ Sodium cacodylate buffer at $\mathrm{pH} 7.2$, and postfixed for $2 \mathrm{~h}$ in $1 \%$ Osmium tetroxide solution and then washed with $0.05 \mathrm{M}$ Sodium cacodylate buffer at $\mathrm{pH}$ 7.2. Dehydration was performed in a grade water-ethanol series (v/v) made to the following concentrations: $50 \%, 75 \%, 90 \%$, $95 \%$ and $100 \%$. And then the specimens were embedded in Spurr's (1969) low-viscosity resin. Ultra-thin sections $80 \mathrm{~nm}$ thick were cut with glass knives on a LEICA Ultracut UCT Ultramicrotome and stained with uranyl acetate and lead citrate and examined under a Carl Zeiss LEO912AB electron microscope.

\section{Results}

Shoots, often accompanied by root and/or callus formation, 


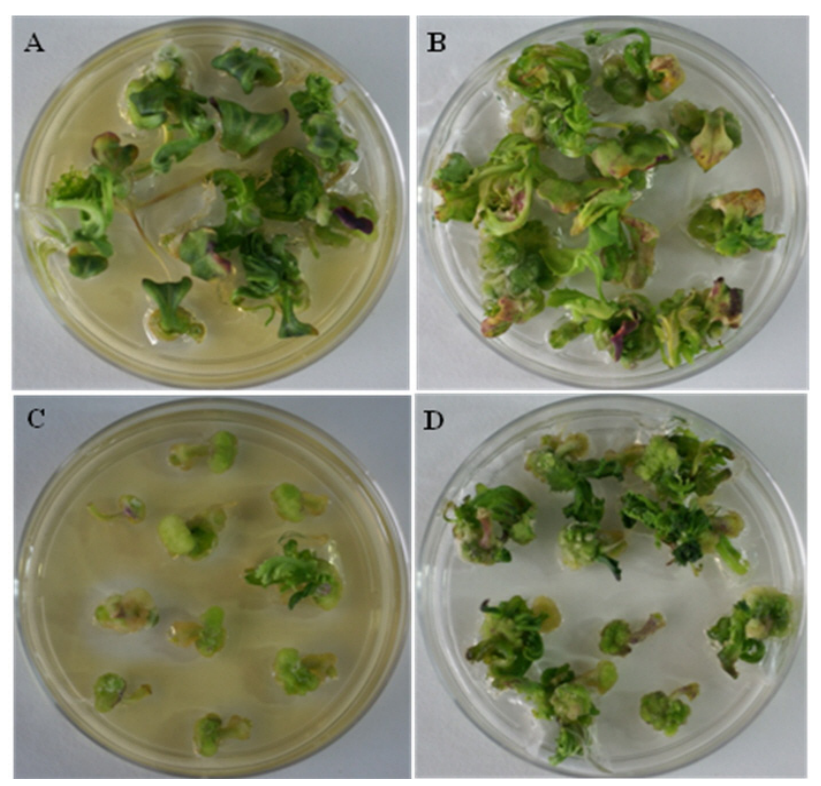

Fig. 1 Shoot regeneration from cotyledon explants with $60 \mu \mathrm{M}$ $\mathrm{AgNO}_{3}$ (a) or cotyledon explants with $40 \mu \mathrm{M}$ STS (silver thiosulfate) (b) or hypocotyl explants with $60 \mu \mathrm{M} \mathrm{AgNO}$ (c) or hypocotyl explants with $\mu \mathrm{M}$ STS (d) of Brassica napus cv. Youngsan after 4-5 weeks of culture were usually differentiated at the cut ends of the cotyledon and hypocotyl explants on the Shoot regeneration medium (SRM) containing ethylene inhibitors (Fig. 1). The medium supplemented with $\mathrm{AgNO}_{3}$ turned light brown color (Fig. 1a, c), but not STS (Fig. 1b, d). In general, shoots began to occur approximately 4-5 days earlier in medium containing STS. Furthermore, shoots from cotyledon explants were observed about 3-4 days earlier than those from hypocotyl explants. Within 3-4 weeks of culture, welldeveloped greenish shoots from cotyledon and hypocotyl explants on medium supplemented with $\mathrm{AgNO}_{3}$ or STS could be seen. Within 4-5 weeks of culture, cotyledons placed on medium became reddish on the margin and eventually shrank (Fig. 1a, b). Most shoots regenerated from cotyledon and hypocotyl explants appeared normal and roots developed in growth regulator-free medium.

With respect to shoot regeneration, cotyledon explants were markedly better than hypocotyl explants and STS was more effective than $\mathrm{AgNO}_{3}$ (Fig. 2). High frequency of shoot regeneration occurred in medium containing STS, particularly at concentrations ranging from 40 to $50 \mu \mathrm{M}$
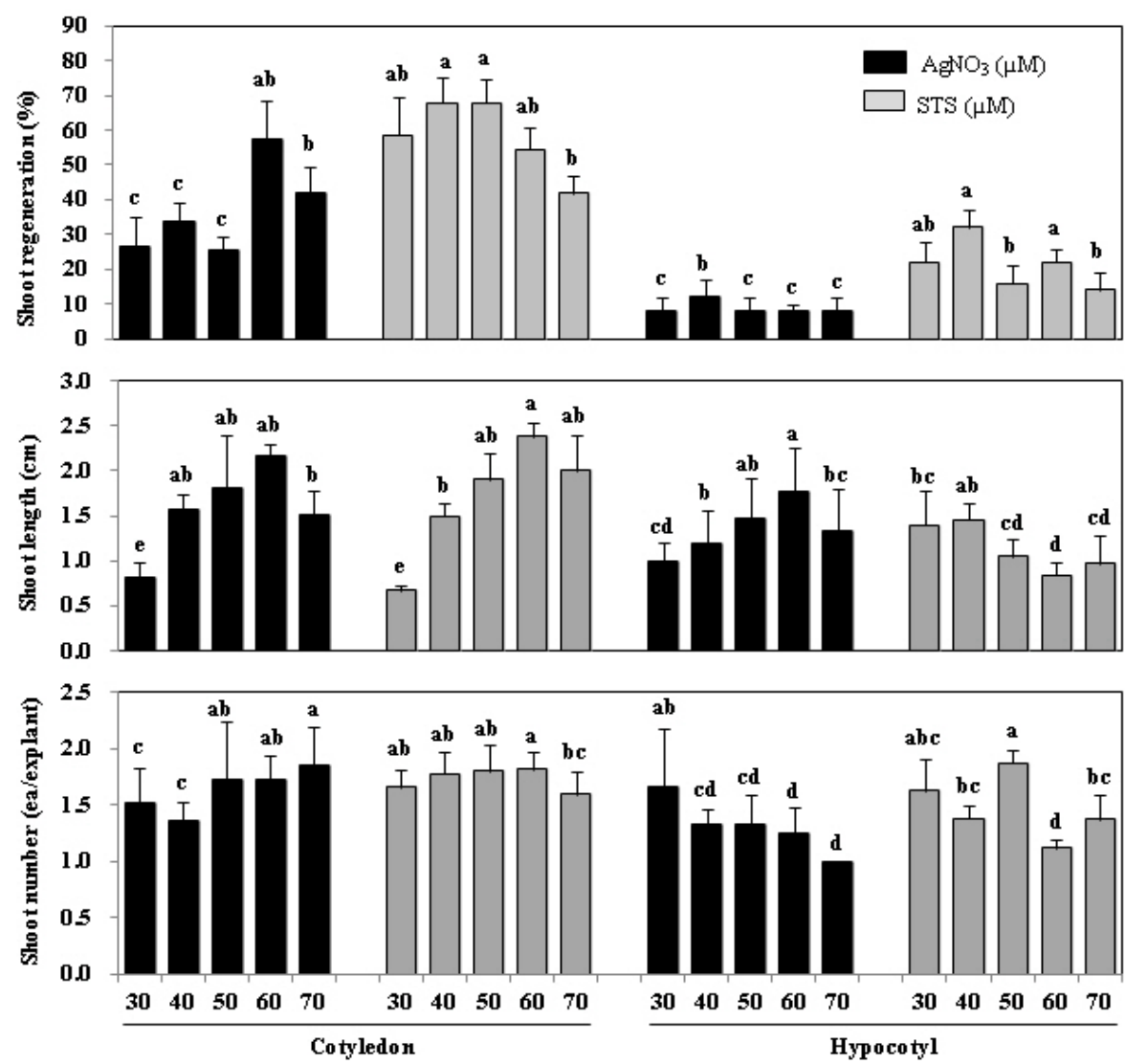

Fig. 2 Effect of silver nitrate $\left(\mathrm{AgNO}_{3}\right)$ and silver thiosulfate (STS) on shoot regeneration from cotyledon and hypocotyl explants of Brassica napus cv. Youngsan. Each value represents the mean of 5 replications each consisting of 10 explants. Error bars indicate the standard error of explants. Different letters indicate statistical difference by Duncan's multiple tests $(\mathrm{P}<0.01)$. Statistical analysis was carried out separately by the plant material (cotyledons and hypocotyls) group 
with cotyledon explants, whereas hypocotyl explants grown on medium containing $\mathrm{AgNO}_{3}$ or STS were poorly regenerative. Shoot length was generally shown a positive correlation to concentrations of STS and $\mathrm{AgNO}_{3}$ at up to 60 $\mu \mathrm{M}$. Although statistics show that the number of shoots differed significantly among individual treatments, there was no a distinct trend depending on the source or concentration of ethylene inhibitor.

To survey whether silver particles are absorbed in the cell of regenerating plantlet and where in the plant cell the silver particles are accumulated, TEM analyses were conducted (Fig. 3). In sections of $80 \mathrm{~nm}$, electron-dense deposits were observed inside the cell, including the plasmodesmata. Silver particles ranging from $10 \mathrm{~nm}$ to $25 \mathrm{~nm}$ were in- vestigated. Discrete heavy accumulation of deposits was widely dispersed inside the cell of regenerating leaf cultured in medium supplemented with $50 \mu \mathrm{M} \mathrm{AgNO}_{3}$ and particularly predominant in the surrounding of the cell wall and plasmodesmata (Fig. 3a). By contrast, in the cell cultured in medium supplemented with $50 \mu \mathrm{M}$ STS finegrained deposits were partly observed in the surroundings of the cell wall (Fig. 3b).

The effect of BAP and TDZ with $50 \mu \mathrm{M} \mathrm{AgNO}_{3}$ on shoot regeneration from cotyledon explants was presented in Table 1. TDZ was more effective for shoot regeneration. TDZ at a concentration of 8-10 $\mu \mathrm{M}$ was good for shoot regeneration; the highest regeneration frequency was $47 \%$ at $8 \mu \mathrm{M}$. However, during BAP treatment shoot induction
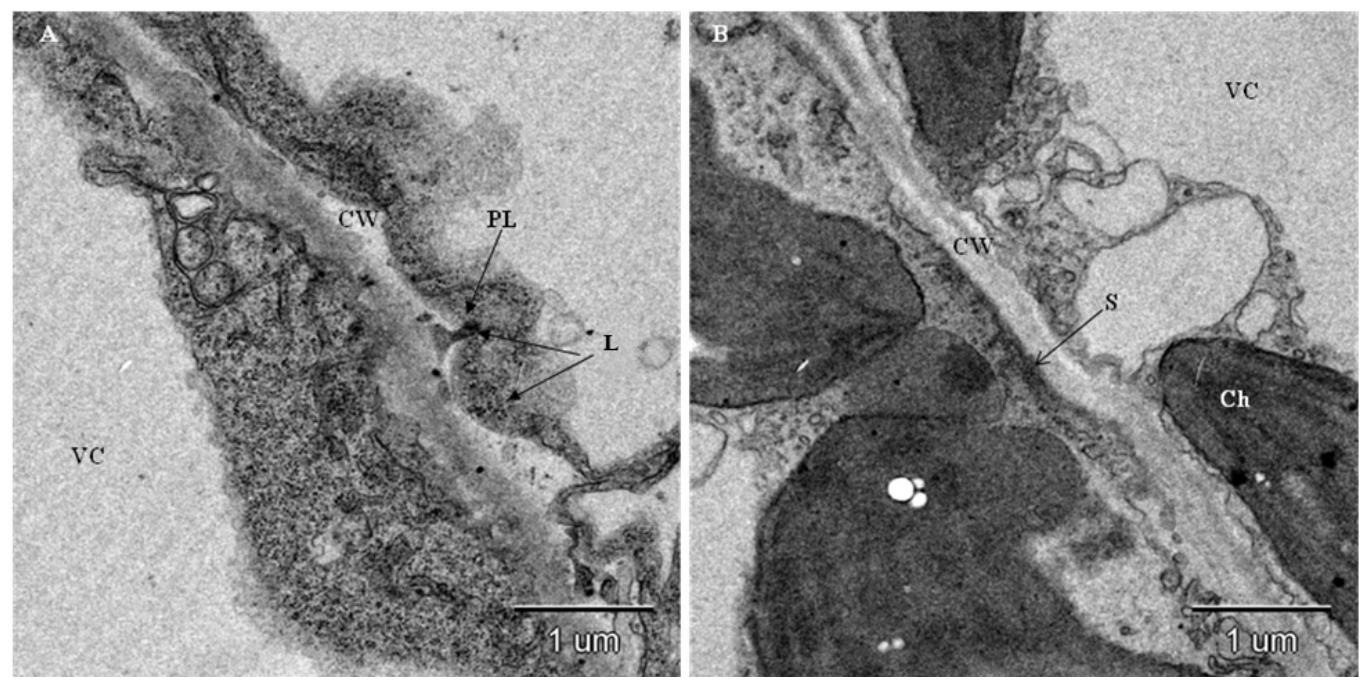

Fig. 3 Electron micrograph of a section through regenerative leaf from cotyledon explant cultured in medium supplement with 50 $\mu \mathrm{M}$ silver nitrate (A) or $50 \mu \mathrm{M}$ silver thiosulfate (B) in Brassica napus cv. Youngsan. Coarse-grained deposits (L) or fine-grained deposits (S) present at the inner side of the cell wall and in the plasmodesmata (PL). $\mathrm{Ch}=$ chloroplast; $\mathrm{CW}=$ cell wall; $\mathrm{VC}=\mathrm{vacuole}$. Magnification 3,150

Table 1 Effects of BAP and $\mathrm{TDZ}$ with $50 \mu \mathrm{M} \mathrm{AgNO}$ on shoot regeneration of cotyledon explants from Brassica napus cv. Youngsan

\begin{tabular}{lcccc}
\hline Cytokinins $(\mu \mathrm{M})$ & Shoot regeneration $(\%)$ & Number of shoots/explant & Length of Shoot $(\mathrm{cm})$ & Fresh weight/explant $(\mathrm{mg})$ \\
\hline BAP 4 & $28 \pm 10 \mathrm{e}^{*}$ & $1.5 \pm 0.2 \mathrm{~b}$ & $2.4 \pm 0.8 \mathrm{ab}$ & $902 \pm 162 \mathrm{ab}$ \\
BAP 6 & $30 \pm 5 \mathrm{~d}$ & $1.5 \pm 0.1 \mathrm{~b}$ & $1.9 \pm 0.2 \mathrm{bc}$ & $738 \pm 108 \mathrm{bc}$ \\
BAP 8 & $29 \pm 7 \mathrm{e}$ & $1.5 \pm 0.5 \mathrm{~b}$ & $2.0 \pm 0.3 \mathrm{~b}$ & $794 \pm 103 \mathrm{bc}$ \\
BAP 10 & $40 \pm 7 \mathrm{ab}$ & $1.5 \pm 0.2 \mathrm{~b}$ & $2.2 \pm 0.3 \mathrm{ab}$ & $590 \pm 109 \mathrm{c}$ \\
BAP 20 & $24 \pm 6 \mathrm{e}$ & $1.3 \pm 0.2 \mathrm{c}$ & $2.2 \pm 0.4 \mathrm{ab}$ & $692 \pm 89 \mathrm{c}$ \\
\hline TDZ 4 & $25 \pm 7 \mathrm{e}$ & $1.4 \pm 0.2 \mathrm{~b}$ & $1.2 \pm 0.6 \mathrm{e}$ & $1042 \pm 120 \mathrm{a}$ \\
TDZ 6 & $36 \pm 5 \mathrm{ab}$ & $1.4 \pm 0.1 \mathrm{~b}$ & $2.8 \pm 0.6 \mathrm{a}$ & $773 \pm 95 \mathrm{bc}$ \\
TDZ 8 & $47 \pm 10 \mathrm{a}$ & $1.4 \pm 0.0 \mathrm{~b}$ & $2.2 \pm 0.5 \mathrm{ab}$ & $796 \pm 99 \mathrm{bc}$ \\
TDZ 10 & $44 \pm 13 \mathrm{ab}$ & $1.6 \pm 0.2 \mathrm{ab}$ & $1.8 \pm 0.3 \mathrm{bc}$ & $672 \pm 32 \mathrm{c}$ \\
TDZ 20 & $41 \pm 6 \mathrm{ab}$ & $1.8 \pm 0.3 \mathrm{a}$ & $1.5 \pm 0.1 \mathrm{~d}$ & $964 \pm 125 \mathrm{ab}$ \\
\hline
\end{tabular}

*Each value represents the mean \pm standard error of 5 replications each consisting of 10 cotyledons. Different letters in the same column indicate significant differences as determined by Duncan's multiple tests at $\mathrm{P}<0.01$ 
Table 2 Effects of ethylene inhibitors/cytokinin combinations on shoot regeneration of cotyledon explants from Brassica napus cv. Youngsan

\begin{tabular}{ccccccc}
\hline $\begin{array}{c}\text { Ethylene inhibitors } \\
(\mu \mathrm{M})\end{array}$ & $\begin{array}{c}\text { Cytokinins } \\
(\mu \mathrm{M})\end{array}$ & $\begin{array}{c}\text { Shoot regeneration } \\
(\%)\end{array}$ & $\begin{array}{c}\text { Number of } \\
\text { shoots/explant }\end{array}$ & $\begin{array}{c}\text { Length of Shoot } \\
(\mathrm{cm})\end{array}$ & $\begin{array}{c}\text { Fresh weight/ } \\
\text { explant }(\mathrm{mg})\end{array}$ \\
\hline $\mathrm{AgNO}_{3} 60$ & BAP 10 & $30 \pm 2 \mathrm{c}^{*}$ & $1.1 \pm 0.1$ & $1.1 \pm 0.5 \mathrm{~b}$ & $821 \pm 103 \mathrm{~b}$ \\
& & TDZ 8 & $38 \pm 3 \mathrm{bc}$ & $1.4 \pm 0.2$ & $1.1 \pm 0.1 \mathrm{~b}$ & $921 \pm 67 \mathrm{~b}$ \\
\hline $\mathrm{STS}$ & 50 & BAP 10 & $52 \pm 5 \mathrm{ab}$ & $1.4 \pm 0.2$ & $1.2 \pm 0.2 \mathrm{ab}$ & $1135 \pm 69 \mathrm{ab}$ \\
& & TDZ 8 & $60 \pm 3 \mathrm{a}$ & $1.5 \pm 0.1$ & $1.4 \pm 0.1 \mathrm{a}$ & $1578 \pm 76 \mathrm{a}$ \\
\hline
\end{tabular}

*Each value represents the mean \pm standard error of 10-15 replications each consisting of 10 cotyledons. Different letters in the same column indicate significant differences as determined by Duncan's multiple tests at $\mathrm{P}<0.05$

was not as effective. Both BAP and TDZ generally had little effect on the number of shoots and shoot length, while fresh weight decreased as the concentration of BAP or TDZ increased. At low levels $(4 \mu \mathrm{M})$ of BAP and TDZ, cotyledons placed on medium were shown a tendency to be enlarged itself (data not shown).

The optimal shoot regeneration response was observed in medium supplemented with $50 \mu \mathrm{M}$ STS $+8 \mu \mathrm{M}$ TDZ (Table 2). The frequency of shoot regeneration ranged from $52 \%$ to $60 \%$ on STS medium, which increased by maximum 2-fold in comparison with $\mathrm{AgNO}_{3}$. Moreover, shoot length and fresh weight was also enhanced in medium supplemented with $50 \mu \mathrm{M}$ STS $+8 \mu \mathrm{M}$ TDZ.

\section{Discussion}

In Solanum tuberosum, leaves from shoot cultures grown in the presence of STS produced much less ethylene (Perl et al. 1988) and STS promoted the shoot regeneration, increasing from 1.2 to 2.3 times the yield of protoplastderived calli and was strongly genotype-dependent (Möllers et al. 1992). In Brassica species, STS showed to be effectual in plant regeneration from peduncle segments of $B$. juncea and $B$. campetris, while $\mathrm{AgNO}_{3}$ improved plant regeneration to a lesser extend in B. napus and B. nigra (Eapen and George 1997). Sridhar et al (2011) showed that STS effectively increased shoot regeneration response as well as average number of shoots from cotyledon and hypocotyl explants in Solanum nigrum. On proliferating root cultures of tomato (Steinitz and Bilavendran 2011), root growth was completely arrested in medium supplemented with $\mathrm{AgNO}_{3}$. However, in medium supplemented with Silver thiosulfate complex, root cultures continued to elongate and proliferate and these results implied Thiosulfate prevented the generation of toxic silver particle precipitates. In this study, we observed that silver particles were accumulated in the cell wall and plasmodesmata of regen- erating leaf on medium supplemented with $\mathrm{AgNO}_{3}$, thus comparatively inhibiting the shoot regeneration. Also, average $68 \%$ shoot regeneration was obtained in $40-50 \mu \mathrm{M}$ STS and this was enhanced by 2-fold compared to that of $\mathrm{AgNO}_{3}$. Therefore, we considered that STS was more effective than $\mathrm{AgNO}_{3}$ on shoot regeneration from cotyledon and hypocotyl explants of $B$. napus.

As seen from Figure 2, the best results of shoot regeneration were $68 \%$ and $32 \%$ from cotyledon and hypocotyl explants respectively. This indicates that cotyledon explants are more regenerative than hypocotyl explants. Chi and Pua (1989) showed that 3-day-old cotyledons were more regenerative than hypocotyls, leaves and stems in $B$. campestris. However, in B. oleracea, hypocotyl explants produced more number of shoots than cotyledons (Msikita and Skirvin 1989). Recent research (Bano et al. 2010) showed that cotyledons were efficient in producing shoots whereas hypocotyls were efficient for callus induction in B. juncea; Also, shoot formation from hypocotyl explants was slower than that from cotyledon explants. Similarly, Chi et al. (1990) reported that shoot formation began to occur earlier about 4 days in cotyledons, compared with hypocotyls. These results correspond to our results.

With TEM analyses, silver nanoparticles were found inside the cell of regenerating leaf from cotyledon explants cultured in medium with $\mathrm{AgNO}_{3}$ or STS. Higher density of silver nanoparticels was shown in the cell of regenerating leaf on medium supplemented with $\mathrm{AgNO}_{3}$, compared with STS. This is assumed as their different solubility. Based on this result, shoot regeneration was shown to be seriously affected by the accumulation of silver nanoparticles in the cell. In addition, this study showed that different silver compounds were acting as a different manner in plant cells. No studies were found that describe the accumulation of silver nanoparticles in regenerating tissue cultured in medium supplemented with a silver compound or how different accumulations of silver nanoparticles in plant cell depending on a silver compound. 
BAP promotes cell division and shoot induction and is generally used in tissue culture of B. napus. By the way, recently the effect on shoot regeneration with TDZ has been reported (Biesaga-Koscielniak et al. 2010). Since TDZ was first reported to have cytokinin activity in 1982, it has been used to induce shoot formation and to promote axillary shoot proliferation and is especially effective with recalcitrant woody species (Lu 1993). In B. juncea (Guo et al. 2005), four kinds of cytokinins were investigated shoot regeneration frequency of cotyledon and leaf segment and TDZ was shown to be best cytokinin to induce shoot compared to BAP, 6-furfurylaminopurine (KT) and $\mathrm{N}-(2-$ chloro-4-pyridyl) -n-phenylurea (CPPU). Besides, TDZ was shown to enhance the number of shoots as well as shoot regeneration in Kalanchoe (Sanikhani et al. 2006) and Pisum sativum (Zhihui et al. 2009). In this study, TDZ was more effective than BAP on shoot regeneration. However, higher both of BAP and TDZ concentrations were shown to be reduced shoot regeneration. And it was not much different on a number of shoots, shoot length and fresh weight between BAP and TDZ. Therefore, we considered that TDZ affected mainly shoot induction on cotyledon explants of B. napus cv. Youngsan. To optimize the efficient and reliable shoot regeneration system from cotyledon explants, the effect on shoot regeneration with different cytokinin/ethylene inhibitor combinations was investigated. In conclusion, high frequency of shoot regeneration was $60 \%$ in medium supplemented with $50 \mu \mathrm{M}$ STS $+8 \mu \mathrm{M}$ TDZ, which was enhanced by 2 -fold compared to that of the control $\left(60 \mu \mathrm{M} \mathrm{AgNO}_{3}+10 \mu \mathrm{M}\right.$ BAP). The protocol reported here may be useful in shoot regeneration of Brassica napus and in genetic improvement by using transgenic approach.

\section{Acknowledgments}

This study was carried out with the support of "Research Program for Agricultural Science \& Technology Development (PJ006793)", National Academy of Agricultural Science, Rural Development Administration, Republic of Korea.

\section{References}

Adams NWH, Kramer JR (1998) Reactivity of Ag+ ion with thiol ligands in the presence of iron sulfide. Environ Toxicol 17:625-629

Apelbaum A, Fisher JB, Burg SP (1972) Effect of ethylene on cellular differentiation in etiolated Pea seedlings. Amer J Bot 59:697-705
Asharani PV, Mun GLK, Hande MP, Valiyaveettil S (2009) Cytotoxicity and genotoxicity of silver nanoparticles in Human cells. ACS Nano 3:279-290

Bano R, Khan MH, Rashid H, Khan RS, Munir I, Swati ZA, Chaudhry Z (2010) Callogenesis and orgarnogenesis in three genotypes of Brassica juncea affected by explants source. Pak J Bot 42:3925-3932

Biesaga-Koscielniak J, Koscielniak J, Janeczko (2010) The impact of zearalenone and thidiazuron on indirect plant regeneration of oilseed rape and wheat. Acta Physiol Plant 32:1047-1053

Chi GL, Pua EC (1989) Ethylene inhibitors enhanced de novo shoot regeneration from cotyledons of Brassica campestris ssp. chinensis (Chinese cabbage) in vitro. Plant Sci 64:243-250

Chi GL, Barfield DG, Sim GE, Pua EC (1990) Effect of $\mathrm{AgNO}_{3}$ and aminoethoxy-vinylglycine on in vitro shoot and root organogenesis from seedling explants of recalcitrant Brassica genotypes. Plant Cell Rep 9:195-198

Chi GL, Pua EC, Goh CJ (1991) Role of ethylene on de novo shoot regeneration from cotyledonary explants of Brassica campestris ssp. pekinensis (Lour) olsson in vitro. Plant Physiol 96: 178-183

De Block M, De Brouwer D, Tenning P (1989) Transformation of Brassica napus and Brassica oleracea using Agrobacterium tumefaciens and the expression of the bar and neo genes in the transgenic plants. Plant Physiol 91:694-704

Eapen S, George L (1997) Plant regeneration from peduncle segments of oil seed Brassica species: Influneces of silver nitrate and silver thiosulfate. Plant Cell Tiss Org Cult 51: 229-232

Gane R (1934) Production of ethylene by some ripening fruits. Nature 134:1008

Guo DP, Zhu ZJ, Hu XX, Zheng SJ (2005) Effect of cytokinins on shoot regeneration from cotyledon and leaf segment of stem mustard (Brassica juncea var. tsatsai). Plant Cell Tiss Org Cult 83:123-127

Harris AT, Bali R (2008) On the formation and extent of uptake of silver nanoparticles by live plants. J. Nanopart Res 10:691-695

Karnovsky MJ (1965) A formaldehyde-glutaraldehyde fixative of high osmolarity for use in electron microscopy. J Cell Biol 27:137A

Lu CY (1993) The use of thidiazuron in tissue culture. In Vitro Cell Dev Biol 29P:92-96

Mazumdar H, Ahmed GU (2011) Phytotoxicity effect of silver nanoparticles on Oryza sativa. International Journal of ChemTech Research 3:1494-1500

Möllers C, Zhangm S, Wenzel G (1992) The influence of silver thiosulfate on potato protoplast cultures. Plant Breeding 108:12-18

Moloney MM, Walker JM, Sharma KK (1989) High efficiency transformation of Brassica napus using Agrobacterium vectors. Plant Cell Rep 8:238-242

Msikita W, Skirvin RM (1989) In vitro regeneration from hypocotyls and seedling cotyledons of tronchuda (Brassica oleracea var. tronchuda Bailey). Plant Cell Tiss Org Cult 19:159-165 
Murashige T, Skoog F (1962) A revised medium for rapid growth and bioassays with tobacco tissue cultures. Physiol Plant 15:473-493

Ono Y, Takahata Y, Kaizuma N (1994) Effect of genotype on shoot regeneration from cotyledonary explants of rapeseed (Brassica napus L.). Plant Cell Rep 14:13-17

Palmer CE (1992) Enhanced shoot regeneration from Brassica campestris by silver nitrate. Plant Cell Rep 11:541-545

Pental D, Pradhan AK, Sodhi YS, Mukhopadhyay A (1990) Variation amongst Brassica juncea cultivars for regeneration from hypocotyl explants and optimization of conditions for Agrobacterium-mediated genetic transformation. Plant Cell Rep 12:462-467

Perl A, Aviv D, Galun E (1988) Ethylene and in vitro culture of potato: suppression of ethylene generation vastly improves protoplast yield, plating efficiency and transient expression of an alien gene. Plant Cell Rep 7:403-406

Poulsen GB (1996) Genetic transformation of Brassica. Plant Breeding 115:209-225

Pua EC, Chi GL (1993) De novo shoot morphogenesis and plant growth of mustard (Brassica juncea) in vitro in relation to ethylene. Physiol Plant 88:467-474

Ratte HT (1999) Bioaccumulation and toxicity of silver compounds: A review. Envrionmental. Toxicology and Chemistry 18: 89-108
Sanikhani M, Frello S, Serek M (2006) TDZ induces shoot regeneration in various Kalanchoë blossfeldiana Poelln. Plant Cell Tiss Org Cult 85:75-82

Sethi U, Basu A, Mukherjee SG (1990) Role of inhibitors in the induction of differentiation in callus cultures of Brassica, Datura and Nicotiana. Plant Cell Rep 8:598-600

Spurr AR (1969) A low-viscosity epoxy resin embedding medium for electron microscopy. J Ultrastruct Res 26:31- 43

Sridhar TM, Preethi D, Naidu CV (2011) Effect of silver thiosulphate on in vitro plant regeneration of Solanum nigrum (Linn.) - An important antiulcer medicinal plant. Current Botany 2:14-16

Steinitz B, Bilavendran AD (2011) Thiosulfate stimulates growth and alleviates silver and copper toxicity in tomato root cultures. Plant Cell Tiss Org Cult 107:355-363

Williams J, Pink DAC, Biddington NL (1990) Effect of silver nitrate on long-term culture and regeneration of callus from Brassica oleracea var. gemmifera. Plant Cell Tiss Org Cult 21:61-66

Yin LY, Cheng YW, Espinasse B, Colman BP, Auffan M, Wiesner M, Rose J, Liu J, Bernhardt ES (2011) More than the ions: the effects of silver nanoparticles on Lolium multiflorum. Envrion Sci Technol 45:2360-2367

Zhihui S, Tzitzikas M, Raemakers K, Zhengqiang M, Visser R (2009) Effect of TDZ on plant regeneration from mature seeds in pea (Pisum sativum). In Vitro Cell Dev Biol 45: 776-782 